\title{
UTOPIAN VISION AND THE AFRICAN NOVEL IN THE 21STCENTURY: A STUDY OF WALE OKEDIRAN'S TENANTS OF THE HOUSE AND JOSEPH EDOKI'STHE UPWARD PATH
}

\author{
Ogbeide Festus Osaro \\ B.A, M.A (English) A.A.U, Ekpoma, Nigeria
}

\begin{abstract}
The thrust of this study is hinged on utopian vision and the African novel. The study revealed the various societal problems in the $21 \mathrm{st}$ century and the literary responses. It showed that, though protest literature has been the literary tool used in locating and proffering solutions as it were, it has not brought about the needed change in the African society. It therefore, recommends a new literary mechanism that can bring about a stable African society. It concludes that utopian literature gives way to reformism that is backed by genuine commitment in art, and the African writers should come to terms with the social commitment by attempting a social re-engineering of the African Society in their literary works.
\end{abstract}

Keywords: Utopian Vision, Tenants of the House,Upward Path

\section{Introduction}

In the pre-independence era, African novelists wrote combative literary works to assert for the continents' identity culturally, and also for their freedom. However, the themes in their works changed immediately after independence. These writers presented their works to show their disapproval of the social political and economic decay in the African society.

Even with the attainment of independence by most African countries which ought to have necessitated a momentous avenue for the African citizens to start enjoying the benefits of independence such as good governance, good roads, portable water, etc; this independence has not led to the fulfillment of the peoples' pre-independence dreams. The high hopes and aspirations of the people were truncated as the people discovered that independence merely replicated the colonial status quo in most cases. This belief is supported by D.S. Izebvaye as quoted by Kolawole Ojungbesan when has says: "With the achievement of national independence, the African eagle might be said to have discovered his identity; but has also become to regard the new ruler as no better than the oppressive colonizer" (53).

In order to alleviate their economic problems and survive the new realities, the African people, especially the youths have engaged themselves in prostitution, emigration, armed robbery, etc.In the contemporary African society social vices have escalated, the hitherto rampant problems immediately after independence 
VS Publications

Alford Council of International English \& Literature Journal(ACIELJ)

Impact Factor:4.401(SJIF)An International Peer-Reviewed English Journal

www.acielj.com

Vol-3,Issue-2 ,2020

ISSN:2581-6500

are almost out of place and are now being replaced by new ones.Common among these new societal problems are advance fee fraud (419), high rate of unemployment, money politics and political godfatherism. All the above are dictated by the prevailing conditions of wants and neglect on the part of the government. These activities of the various governments in African countries have equally caused tensions and varied flow of literary responses. African literary writers as the recorders of the societal mores of their age have therefore become waterdogs of their society, detaining the follies and absurdities; no matter how reprehensible; but also suggesting an alternative course of action that will bring about redemption. In line with this, Wole Sayinka posits that:"it is about time that the African writer stopped being a mere chronicler and understood also that part of his purpose is to write with a definite vision, he must at least begin by exposing the future in a clear and truthful exposition of the present" (2).African writers, with no better option as it were, decided to use protest literature as a literary tool since dialogue between the leaders and the people has not brought about the needed change. As a result of the above, Chinaka Madu affirms that:

Failure to discover any other means of pressurizing the government in finding lasting solutions to the needs and aspirations of the people, revolutionary violence has fast and popularly become a handy tool for the oppressed to gain attention for negotiation with the oppressor in order to seek redress.
The reason for the above poser, according to Peter Oyekachi is that; "Revolutionary aesthetic is a response to economic and socio-political stratification. It is enshrined in the organic relationship between the socio-political and economic ideology of the literary component of the society" (50).This is why Africa writers such as Chinua Achebe in A Man of the Peoplesatirizes the new government in Nigeria immediately after independence. Chimamanda Ngozi Adichie, in her book Americanah, condemns the problems leading to emigration that have become a problem in Africa due to political disenfranchisement, poverty, war, and bad government. Violence by Festus Iyayi also responded to the various societal problems hindering the growth and development in Africa.

Wale Okeduran in the text under review, has equally demonstrated the revolutionary aesthetic, a response to economic and socio-political stratification, but has, as usual, met with the same fundamental problem or not bringing about the total or the needed change. Despite the presence of several literary works written on different sociological backgrounds, there exist the aforementioned societal vices in the African society. Hence, the need for a visionary or utopian literature. Utopian or visionary literature uses the opposite characteristics of realism to satirize the various societal Butts. In my erstwhile unpublished article, I posit that; "utopian literature is fasting becoming a tool for satirizing the societal Butt: illpraising, as some critics may call it, but it is a modern satire, when deeply understood" (23). African writers replicate 
VS Publications

Alford Council of International English \& Literature Journal(ACIELJ)

Impact Factor:4.401(SJIF)An International Peer-Reviewed English Journal

www.acielj.com

Vol-3,Issue-2,2020

ISSN:2581-6500

these ills in the African society repeatedly as they occur in their works, but no meaningful achievements have been recorded. As a result of this there is the need for a paradigm shift from this style of documenting the societal elements in their literary works. This brings to the fore the literary proposal of Femi Osofisan, a literary icon in his work titled The City as Muse: Ibandan and the Efflorescence of Nigerian Literaturewhere he says: "There is the need to counter this new literature of incurable angst with another that offers a more perspective of life, a literature that will encourage us to struggle and not to be beaten down by despair "(12). This same concern has also been expressed by no less an eminent critic of African literature, Charles Nnolim, because he believes that the major preoccupations of African literature in the 20th century tended to make it claustrophobic. In an article titled "African Literature in the 21stCentury; Challenges for Writers and Critic", he asserts; "that a new image of the African personality needs to be fashioned, to reposition Africa for the take-off the 21st century. Weneed a new spiritual orientation, a new spirit of optimism, an Africa full of promise, able to feed its teeming population, with a healthy and vibrant people not dependent on Europe and America for sustenance" (3).African writers, who play the role of the sensitive point' in their various communities should be at the fore front in re-educating and regenerating their people as this has become a necessity in the African society since protest and revolutionary literature have not fully changed the actions and inactions of the societal Butts. Hence, the need for modern satire (utopian literature), where the societal Butts would be shown the wary to make amend in his/her ways in order to pave way for a stable society since the writer is a teacher.

\section{Utopian Vision in Tenants of the House}

Tenants of the Houseis a tale that unearths the putridity in the house known as the legislative arm of government. The author succeeds in differentiating between appearance and reality through the novel elucidating that there is a difference between reality and the actions put up by the politicians. Wale Okeduran's Tenants of the House is a warning to a nation at the precipice of self destruction, to book it awake as it is not yet Uhuru.The text shows that moral principles, tolerance for opposition, and most importantly, the use of powers to the benefit of the people do not have much meaning to the politicians as they scramble for the most lucrative offices and appointments.

The noveltells the story of Honourable Samuel Bakura, a naïve first term member of the house of representatives. His dreams of contributing his quota as alawyer towards the enactment of laws that will impact the lives of the citizens are truncated. He discovers that, much to his shock that most of the honourable members have hidden agenda which are anything but honourable. His first baptism of fire is when he sees a gun in honourable Elizabeth's bag. He wonders what a gun would be doing in her bag, and his is jolted awake by this revelation as he asks;

What did guns have to do with serving one's country?. Should I have come to the parliament.Now, I thought, it was too late to go back, the road here was hard. To get 
VS Publications

Alford Council of International English \& Literature Journal(ACIELJ)

Impact Factor:4.401(SJIF)An International Peer-Reviewed English Journal

www.acielj.com

Vol-3,Issue-2,2020

ISSN:2581-6500

my nomination confirmed at the constituency level had been a fierce struggle. I had coughed up half my annual income for the nomination but it was not enough (4).

Honourable Elizabeth educates him further when she says;

"Huge loads of fertilizer is what you need, money, money, money is the fertilizer of politics ..." (4)Sam, in his naivety, and perhaps due to the measuring effects of seeing so much money for the first time in his life, the character narrator is drafted to unseat the speaker of the House of Representatives. He soon learns that in politics scruples could go to blazes; all that matters is the self, for there are no permanent interests. However, having met with the speaker, Yahaya, the soul-stirring words from the latter strengthen his resolve to henceforth listen to his conscience in his future dealings. Hence, he says; "I was about the best educated. Who of our group know about Clauselvitz or Plato? or Socrates? Education and gangsterism do not go well together. And instead of my current alignment with political gangsterism, I should use my education and experiences as a lawyer in a more positive way; promoting bills and polices which would move the nation forward" (57).

Sam, having made this avowal, rises with the students and workers in the country to help the speaker escape the impeachment move in the house. Hefought and won the battle of impeachment with the speaker's group, The climax of Sam Bakura's shock of how politics should be played without regard to conscience was when he discovers that the president has co-opted the same speaker he sought to impeach some months ago to spearhead his infamous dream of tenure elongation. One is baffled like Sam Bakura of the prostitute-like change of language such that the now pro-president speaker could try to persuade the central character, Sam with the following words:

Samuel, are you really a politician? Have you forgotten the saying No permanent friends; only permanent interests? Let me tell you, the president was against me in the past, now he is for me.Two, the North, the people of the North? They are an amorphous sociological mass, not a political entity. The people, which people? Our hungry passive constituents? What do they care about, politics? The hungry masses would go for anything at any rate, my own take. What is at stake for us is to give the president our support. Life is a risk and this is a good risk. If the plan succeeds all is well and good, if it doesn't, we have nothing lose, you and I, Sam all of us would at least gain some money (167).

Bakura, though timid and politically unprincipled in the early part of the novel, at this stage would not be moved by such speeches to support a plan that would truncate the country's nascent democracy. He boldly advises the speaker to shelve his lady Macbeth-like ambition. As he says: "My feeling is that here in this country the ideal may not fly let us not lose it all the goodwill we have amassed over the years" (184). He bravely refuses bribes from the president and his cohorts, dares intimidations and threat to his life, thereby 
VS Publications

Alford Council of International English \& Literature Journal(ACIELJ)

Impact Factor:4.401(SJIF)An International Peer-Reviewed English Journal

www.acielj.com

Vol-3,Issue-2,2020

ISSN:2581-6500

contributing to the killing of that selfish dream.

On the extreme divide is honourable Elizabeth Bello, who unlike Sam is well acclimatized to the murky waters of the male dominated world of politics. She tries to offer herself to Sam to enliven his weakening interest in the impeachment plan against the speaker.She uses what she has to get what she wants. This act of trying to seduce Sam in order to retain him in Wenike's group is selfishness as Oseghale and Egede opine,"this vividly exemplifies the extent to which most women can go in life to achieve their parochial aim" (99). Honourable Sam Bakura, stand his ground as a true noble man, fights for his country and makes sure he stands for what is right.This action of Sam can be likened to Fernando the great in Joseph Edoki'sThe African Dream when he was offered some money as a bribe by Ozid in order to attract personal gains to the determent of the people. Fernando reacts thus: "I don't need that kind of gift, ok? I suggest you donate the one million dollars to our schools and research institutes to the poverty society of Africa" (231). Okediran shows in this text that people should always do the needful rather than crippling the nation's economy. He has equally fictionalized that protest is not the only way to resolve issues.

\section{Utopian Vision in Edoki's The Upward Path}

Edoki, in the text portrays good government and its sustainability. This clearly states the need for improvement on what has been done by past administrations. The ideal put up in this text by such a distinct African writer is quite unique in that he reverses all the features of realism which has before now become a common phenomenon in most African novels. Rather than fictionalizing what is actually on ground as it were, he presents a rather stable African society. This singular act may be misinterpreted to be non-commitment, but it is an attempt to further extend satire as an artistic creed.This novel supports the re-invention of Africa in the twenty first century and canvasses for the propagation of democracy, good governance and the regeneration and re-inscription of Africa's image. The novel according to Agho: "is Inspiring and project a forward looking utopia to Africa" (13). Again, according to Nnolim, "should project a truly independent Africa, politically stable, able to feed her starving peoples, standing side by side with Europe and the west, possessing enough coercive force to earn her respect in the intimation arena, and become the last refuge for the oppressed all over the world" (5). This is what one finds is this text because it is a mockery of the entire African democratic scene as what is on ground is the opposite of what the author proselytized.

The Upward Path is a documentation of the visit of Mr. Gaga, a Rwandan- American researcher from America to savannah. It can be seen from the first page of the text that Mr. Gaga is able to confirm the various negative images Africa is portrayed in the western world. These images were revealed to him when he listened to the news about Africa on television. The portrayal of these 
VS Publications

Alford Council of International English \& Literature Journal(ACIELJ)

Impact Factor:4.401(SJIF)An International Peer-Reviewed English Journal

www.acielj.com

Vol-3,Issue-2,2020

ISSN:2581-6500

negative images in the text actually shows that African is in a mess, but to cue into this new literature of hope and to show African leaders how to lead the people, he decided to be visionary is his approach. Mr. Gage soon discovers that what he heard on television was wrong. However, he feels reluctant to accept the statistics of the development about savannah's economic transformation because it does not in any way align with what he has heard and known about Africa's poverty in the western world. He therefore, rejected the statistics provided by the Director General of the office of National Planning Commission about the self-sufficiency and the economic indices of progress and development of Savannah because it proves the continent in the western world wrong.

Mr. Gaga's belief is further worsened when he visits Yakubo to meet Mr. Bello, who lives in a farming community called Greenville. He sees the good roads, many workers in Mr. Bello's farm that he pays wages at the end of every month, his land cruiser jeep, etc. He also discovers that no burglary incidents had been recorded in Timbuktu Street in ten years. His very lavish reception for Mr. Gaga and even his edifice surprise the latter to the extent that he wonders and said to himself: "American and European farmers can't even afford this. There must be something ugly underneath this beautiful scenery. "Nobody can convince me that African farmers can afford such luxury flats" (22).

In Greenville community, there is no power failure, even Mr. Bello's daughters born ten years before Gaga's visit had never seen a candle before, since there had never been power failure since they were born.He is further startled by the fact that Savannah has a responsible government that gives patient right to anybody that discovers or invents something new and good. The enormity of Gaga's discoveries according to Agho:"Jolts him out of the lethargic recesses of his earlier fixative concerning Africa. Instead of the horrendous specters of war-ravaged communities, women and children and the sprawling poverty which he had hoped to find in Savannah, he finds wealth, splendor and maxima equitable utilization of resources by the government to foster good development and bring about peace, a crime free society and a satiated citizenry. He not only jettison his research, which he now finds to be based on faulty premises; he extends his three months visit to the country by deciding to live, work and possibly find a home in Savannah" (12)

All the above are made possible because Edoki believes in the ideal of Craig Vincent Smith when he says: "the desire to re-imagine the nation to constitute it anew, at any and all scales is the life blood of utopia" (4). Sir Thomas Moore also concludes that utopian literature oscillates between satirical and darkly comical when he says: "therefore, we must recognize there is in utopia's construction and utilization a tension between reality and fiction" (3). Edoki's ability to construct and utilize the tension between reality and fiction makes this text unique and most importantly satirical. What Edoki has done in this text is to encourage African leaders to pay attention 
VS Publications

Alford Council of International English \& Literature Journal(ACIELJ)

Impact Factor:4.401(SJIF)An International Peer-Reviewed English Journal

www.acielj.com

Vol-3,Issue-2,2020

ISSN:2581-6500

to the development of the continent and imbibe the rubies on good governance, good leadership, transparency, accountability and eschew corruption. He believes African can be great again and even greater if African leaders lead the people well. This is what the text portrays.

\section{References:}

[1]Achebe, Chinua. AMan of the People. London: Heinemann, 1966. Print.

[2]--- . "The Role of the Writer in a New Nation." African Writers on African Writing. London: Heinemann, 1973. Print. [3]Agho, Jude. Standpoints on the African Novel. Jos: Jubilee Press, 2000. Print.

[4]---- .From Protest to Assent: Unravelling the African Novel as a Protean Art. 40th Inaugural Lecture, AmbroseAlli University, Ekpoma. Ekpoma: Univ. Printing Press,2011.

Print.

[5]Egede, Benji and Francis, Oseghale. "Theme of Social and Mortal Decadence in Wale Okediran's Strange Encounter". O.S. Odiagbe (ed) Journal of Global and social Studies. Ekpoma: Gsplus International, 1, 2 (2011): 72 - 80. Print.

[6]Iyayi, Festus. Violence. London: Longman, 1979. Print.

[7]Izevbaye, Dennis. S. "The Relevance of Modern Literary Theory in English to Poetry and Fiction in English - Speaking West Africa". An Unpublished PhD Thesis Submitted to the English Department, University of Ibadan. Print.

[9]Ihonvbere, Julius. "Reinventing Africa for the Challenges of the Twenty-first Century". The Challenges of Leadership and Development in Africa. Theory and Praxis: Selected Essays of Julius O.
Ihonvbere .Ed. Monday Lewis Igbafen. Ibadan: Book Wright Publishers, 2012. Print.

[10]Madu, Chinaka. "Demythologizing the Masquerade of Violence in the Niger Delta Creek": From Boom to Doom: Protest and Conflict Resolution in the Literature of the Niger Delta. Ed. Chinyere Nwahunaya. Owerri: Springfield Publishers Limited, 2011. Print.

[11]More, Thomas. The Utopia Vision. San Diego: Sullivan Press, 1983. Print. [12]Nnolim, Charles. "African Literature in the 21st Century, Challenges for Writers and Critics". New Directions in African Literature. ALT. 36, 25 (2012): 1-9. [13]Print.Nwahunanya, Chinyere. "Introduction: From Boom to Doom- The Niger Delta in Contemporary Nigerian Literature". From Boom to Doom: Protest and Conflict Resolution in the Literature of the Niger Delta. Ed. Chinyere Nwahunanya. Owerri: Springfield Publishers Limited, 2011. Print.

[14]Okediran, Wale. Strange Encounters. Ibadan: Heinemann, 2004. Print.

[15]--- .Tenants of the House. Ibadan: Nelson Publishers Ltd.; 2010. Print.

[16]Osaro, F. Ogbede. Socio-political malaise in the African novel: A study of Wale Okediran' strange encounters, The Tenants of the House, and Joseph Edoki's The African Dream and Upward Path(unpublished master's thesis), 2017: 36. Print.

[17]Osofisan, Femi. The City as Muse: Ibadan and the Efflorescence of Nigerian Literature. Ibadan: Hope Publications Ltd; 2007. Print.

[18]Oyekachi Peter .O. "The Theme of Exploitation and Official Complicity in the Autobiographies of Ken Saro Wiwa's A 
VS Publications

Alford Council of International English \& Literature Journal(ACIELJ)

Impact Factor:4.401(SJIF)An International Peer-Reviewed English Journal

www.acielj.com

Vol-3,Issue-2 ,2020

ISSN:2581-6500

Month and Day: A Detention Diary".

(Unpublished Thesis), University of

Calabar: Department of English and Literary Studies. (2012): 11 - 12. Print.

[19]Smith Craig. V. "Utopia and Necessity: The Crises of Nationalism in African Literature". (January 1, 1993) Paper AA19321481.
http://repository.upenn.edu/dissertations/A A19321481.

[20]Soyinka, Wole. Myth, Literature and the African World. Cambridge: Cambridge University Press, 1972. Print.[21]--.Petals of Blood. London: Heinemann, 1977. Print. 